\title{
Pemodelan Molekuler Peptida Bioaktif Laut sebagai Antikoagulan Alami terhadap Enzim Sitokrom P450 (CYP) 2C9
}

\section{(Molecular Modelling of Marine Bioactive Peptides as Natural Anticoagulants against Cytochrome P450 (CYP) 2 C9 Enzymes)}

\author{
Taufik Muhammad Fakih*, Mentari Luthfika Dewi \\ Program Studi Farmasi, Fakultas Matematika dan Ilmu Pengetahuan Alam, Universitas Islam Bandung, Bandung, \\ Indonesia. \\ *E-mail: taufikmuhammadf@gmail.com
}

\author{
Article Info: \\ Received: 18 Maret 2020 \\ in revised form: 10 Mei 2020 \\ Accepted: 04 Oktober 2020 \\ Available Online: 04 Oktober 2020 \\ Keywords: \\ Anticoagulant \\ Cytochrome P450 (CYP) 2C9 \\ Marine Bioactive Peptides \\ Protein-Peptide Docking \\ In silico Study \\ Corresponding Author: \\ Taufik Muhammad Fakih \\ Program Studi Farmasi \\ Fakultas MIPA \\ Universitas Islam Bandung \\ Bandung \\ 40116 \\ Indonesia \\ email: \\ taufikmuhammadf@gmail.com
}

\begin{abstract}
Anticoagulants are very important for the treatment and prevention of thrombotic disorders. The use of conventional anticoagulants like heparin and warfarin can cause bleeding complications. To find safer anticoagulant therapy agents, the development of isolation of new anticoagulant compounds has shifted towards natural sources. Bioactive peptides can be considered a better alternative because of their therapeutic potential in the treatment of various diseases. Several peptide molecules have been shown to inhibit the cytochrome P450 (CYP) 2C9 enzyme as a natural anticoagulant, such as bioactive peptides produced by yellowfin sole (Limanda aspera) and bioactive peptides in blue mussel (Mytilus edulis). This study aims to identify and evaluate the interactions that occur between peptide molecules with the cytochrome P450 (CYP) 2C9 enzyme using protein-peptide docking methods. Bioactive peptide sequencing was modeled using the PEP-FOLD software. The best conformation was chosen for an interaction study against the macromolecule of cytochrome P450 (CYP) 2C9 enzyme using PatchDock software. Further observations were made for the interactions by using BIOVIA Discovery Studio 2020 software. Based on the results of protein-peptide docking, the yellowfin sole peptide molecule has a good affinity against the macromolecule of cytochrome P450 (CYP) 2C9 enzyme, with an ACE score of -2527.01 kJ / mol. Therefore, the bioactive peptide is predicted to be used as a candidate for the cytochrome P450 (CYP) 2C9 enzyme inhibitor.
\end{abstract}

Copyright $\odot 2019$ JFG-UNTAD

This open access article is distributed under a Creative Commons Attribution (CC-BY-NC-SA) 4.0 International license.

How to cite:

Fakih, T. M., \& Dewi, M. L. (2020). Pemodelan Molekuler Peptida Bioaktif Laut sebagai Antikoagulan Alami terhadap Enzim Sitokrom P450 (CYP) 2C9. Jurnal Farmasi Galenika :Galenika Journal of Pharmacy (e-Journal), 6(2), $347-355$. doi:10.22487/j24428744.2020.v6.i2.15041 


\section{ABSTRAK}

Antikoagulan sangat penting untuk pengobatan dan pencegahan penyakit trombotik. Penggunaan antikoagulan konvensional seperti heparin dan warfarin dapat menyebabkan komplikasi perdarahan. Dalam upaya pencarian agen terapi antikoagulan yang lebih aman, maka pengembangan isolasi senyawa antikoagulan baru telah bergeser dengan memanfaatkan sumber-sumber alami. Peptida bioaktif dapat dianggap sebagai alternatif yang lebih baik karena potensi terapeutiknya dalam pengobatan berbagai penyakit. Terdapat beberapa molekul peptida yang telah terbukti dapat menghambat enzim sitokrom P450 (CYP) 2C9 sebagai antikoagulan alami, seperti peptida bioaktif yang dihasilkan oleh ikan tuna sirip kuning (Limanda aspera) dan peptida bioaktif kerang biru (Mytilus edulis). Penelitian ini bertujuan untuk mengidentifikasi dan mengevaluasi interaksi yang terjadi antara molekul peptida dengan enzim sitokrom P450 (CYP) 2C9 menggunakan motode penambatan molekuler berbasis protein-peptida. Sekuensing peptida bioaktif terlebih dahulu dimodelkan dengan menggunakan software PEP-FOLD. Konformasi terbaik dipilih untuk dilakukan studi interaksi terhadap makromolekul enzim sitokrom P450 (CYP) 2C9 dengan menggunakan software PatchDock. Pengamatan lebih lanjut dilakukan terhadap interaksi yang terbentuk dengan menggunakan software BIOVIA Discovery Studio 2020. Berdasarkan hasil dari penambatan molekuler berbasis protein-peptida, molekul peptida ikan tuna sirip kuning memiliki afinitas yang baik terhadap makromolekul enzim sitokrom P450 (CYP) 2C9, yaitu dengan ACE score $-2527,01 \mathrm{~kJ} / \mathrm{mol}$. Oleh karena itu, peptida bioaktif tersebut diprediksi dapat digunakan sebagai kandidat inhibitor enzim sitokrom P450 (CYP) 2 C9.

Kata kunci: Antikoagulan; Enzim Sitokrom P450 (CYP) 2C9; Peptida Bioaktif Laut; Penambatan Molekuler Berbasis Protein-Peptida; Studi In silico.

\section{PENDAHULUAN}

Trombosis merupakan keadaan berkurangnya aliran darah di dalam pembuluh darah yang diakibatkan oleh proses pembekuan darah (Mackman, 2012). Proses tersebut melibatkan interaksi kompleks endotelium vaskuler, trombosit, dan faktor pembekuan lain sehingga akhirnya bermanifestasi sebagai tromboemboli vena (VTE), meliputi trombosis vena dalam (DVT) dan emboli paru (PE) atau sindrom koroner akut (Mega dan Simon, 2015). Kematian yang disebabkan oleh trombosis hingga saat ini masih menjadi perhatian. Menurut Raskob et al., (2014), trombosis merupakan faktor risiko utama beban penyakit global. Oleh karena itu, terapi antikoagulasi menjadi alternatif untuk pencegahan dan pengobatan trombosis (Alquwaizani et al., 2013), tromboemboli vena (Franchini dan Mannucci, 2016), stroke iskemik akut (Patterson et al., 2006), serta fibrilasi atrium (Katritsis et al., 2015).

Terapi trombosis secara konvensional dapat menggunakan heparin dan warfarin yang telah digunakan sebagai antikoagulan dalam pengobatan klinis (Hawkins, 2004). Heparin diberikan kepada pasien yang membutuhkan antikoagulasi parenteral, sedangkan warfarin untuk pasien yang membutuhkan antikoagulasi oral (Harter et al., 2015). Warfarin adalah antagonis vitamin-K (VKA) yang bekerja dengan cara menghambat sintesis faktor pembekuan darah. Sementara heparin merupakan campuran heterogen dari polimer polisakarida yang biasanya dihasilkan dari mukosa usus babi. Heparin memiliki berat molekul rata-rata $15 \mathrm{kDa}$, tetapi setelah mengalami proses pembelahan fraksi berat molekul heparin menjadi lebih rendah ( $\sim 5 \mathrm{kDa})$ (Hawkins, 2004). Meskipun kedua antikoagulan tersebut berkhasiat pada dosis yang tepat, namun memiliki sejumlah faktor pembatas yang dapat menimbulkan efek samping. Pendarahan merupakan masalah serius dari penggunaan warfarin (Snipelisky dan Kusumoto, 2013). Keterbatasan lainnya adalah adanya interaksi dengan makanan kaya vitamin K dan dapat melemahkan atau bahkan menghilangkan efek warfarin (Hawkins, 2004). Selain itu, efek samping utama heparin adalah dapat menginduksi perkembangan trombositopenia (Ahmed et al., 2007).

Enzim sitokrom P450 (CYP) 2C9 merupakan komponen utama dari subfamili CYP2C yang terdapat dalam hati manusia dan terlibat dalam oksidasi beberapa senyawa endogen dan xenobiotik, serta memainkan peranan penting dalam metabolisme warfarin. Metabolisme warfarin yang diperantarai oleh CYP2C9 dapat menghasilkan produk yang aman atau beracun, hal tersebut terkait dengan mode pengikatan antara warfarin dengan CYP2C9 (Suguna et al., 2014). Dengan demikian, diperlukan kandidat antikoagulan alami yang memiliki aktivitas lebih baik dari warfarin dan heparin serta toksisitas 
rendah. Beberapa penelitian yang telah dilakukan sebelumnya membuktikan bahwa terdapat peptida bioaktif laut yang memiliki aktivitas terhadap CYP2C9 sebagai antikoagulan, antara lain peptida bioaktif TDGSEDYGILEIDSR yang berasal dari ikan tuna sirip kuning (Limanda aspera) (Rajapakse et al., 2005) dan peptida EADIDGDGQVNYEEFVAMMTSK yang berasal dari kerang biru (Mytilus edulis) (Jung dan Kim, 2009).

Oleh karena itu, penelitian ini bertujuan untuk mempelajari, mengidentifikasi, dan mengevaluasi interaksi yang terjadi antara petida bioaktif dengan enzim sitokrom CYP2C9 menggunakan studi penambatan molekuler berbasis protein-peptida. Penelitian ini menekankan energi interaksi yang terbentuk dan residu asam amino yang bertanggung jawab dalam pengikatan protein-peptida. Kemudian, berdasarkan hasil penelitian diharapkan informasi terkait peptida yang mampu berinterakasi dengan baik terhadap CYP2C9 sehingga dapat dijadikan struktur peptida acuan dalam pengembangan antikoagulan alami.

\section{METODE PENELITIAN}

\section{Alat dan Bahan}

Bahan yang digunakan dalam penelitian ini adalah struktur kristal makromolekul enzim sitokrom P450 (CYP) 2C9 yang telah membentuk kompleks dengan warfarin. Makromolekul target tersebut diperoleh dari web Protein Data Bank (http://www.rcsb.org/pdb) dengan kode PDB 1OG5 dan memiliki resolusi 2,55 $\AA$ (Gambar 1) (Akif et al., 2011). Molekul peptida bioaktif yang digunakan dalam penelitian ini merupakan peptida bioaktif yang memiliki aktivitas terhadap CYP2C9 dan telah dibuktikan pada penelitian sebelumnya. Sekuensing dari peptida bioaktif tersebut antara lain TDGSEDYGILEIDSR yang berasal dari ikan tuna sirip kuning (Limanda aspera) dan EADIDGDGQVNYEEFVAMMTSK yang berasal dari kerang biru (Mytilus edulis) (Wang et al., 2017). Perangkat lunak yang digunakan diantaranya terdapat Sistem Operasi Windows 10 dan Linux Ubuntu 18.10, MGLTools 1.5.6 yang dilengkapi dengan AutoDock 4.2, PEP-FOLD (http://bioserv.rpbs.univ-paris-diderot.fr/PEP-FOLD/), PachDock, serta BIOVIA Discovery Studio 2020. Perangkat keras yang digunakan adalah komputer dengan spesifikasi processor Intel (R) Core i3-6100 CPU @ 2.30GHz (4 CPUs), memory 4096 MB RAM, Harddisk 320GB, dan VGA Intel HD Graphics 520.

\section{Metode}

\section{Preparasi Makromolekul Enzim}

Struktur kristal makromolekul enzim yang telah diunduh dari web Protein Data Bank selanjutnya dilakukan preparasi terlebih dahulu menggunakan software MGLTools 1.5.6 yang dilengkapi dengan AutoDock 4.2. Preparasi makromolekul enzim ini dilakukan dengan menghilangkan molekul air dan ligan alami, kemudian dilanjutkan dengan menambahkan atom hidrogen polar dan menghitung muatan parsial Kollman (Kurniawan et al., 2018).

\section{Identifikasi Sisi Aktif Makromolekul Enzim}

Makromolekul enzim yang telah dilakukan preparasi kemudian diidentifikasi dan dievaluasi bagian sisi aktif pengikatan yang berperan terhadap aktivitas antikoagulan dengan menggunakan software BIOVIA Discovery Studio 2020 (Kemmish et al., 2017). Molekul warfarin yang merupakan ligan alami dari makromolekul target enzim sitokrom P450 (CYP) 2C9 digunakan untuk mengidentifikasi dan mengevaluasi area sisi aktif dari makromolekul enzim tersebut. 


\section{Pemodelan Molekul Peptida Bioaktif}

Pemodelan molekul bioaktif peptida dilakukan dengan menggunakan server PEP-FOLD (http://bioserv.rpbs.univ-paris-diderot.fr/PEP-FOLD/) (Gambar 3). Server PEP-FOLD merupakan suatu software yang digunakan untuk memodelkan sekuensing peptida menjadi konformasi 3D secara de novo dengan jumlah asam amino antara 9 sampai 25 (Chavan dan Deobagkar, 2015).

\section{Studi Penambatan Molekuler Berbasis Protein-Peptida}

Studi penambatan molekuler berbasis protein-peptida dilakukan dengan menggunakan software PatchDock untuk mengamati dan mengidentifikasi interaksi yang terjadi antara makromolekul enzim sitokrom P450 (CYP) 2C9 dengan molekul peptida bioaktif. Jarak antara bagian permukaan makromolekul enzim dan molekul peptida bioaktif dibatasi dengan batas radius maksimum 4.0 Å. Studi penambatan molekuler ini menggunakan parameter dengan berdasar pada representasi bentuk molekul, bagian sisi aktif pengikatan makromolekul target, serta pemilihan dan penilaian. Studi penambatan molekuler ini juga dilakukan secara efisien tanpa adanya ikatan antar molekul yang bersifat rigid (Aruleba et al., 2018).

\section{Analisis Hasil Studi Penambatan Molekuler Berbasis Protein-Peptida}

Hasil penambatan molekuler berbasis protein-peptida kemudian dilakukan identifikasi dan evaluasi terhadap interaksi yang terjadi antara makromolekul enzim sitokrom P450 (CYP) 2C9 dengan peptida bioaktif berdasarkan Atomic Contact Energy (ACE) score (Prabhu dan Rajeswari, 2016). Residu asam amino yang berperan dalam interaksi molekuler yang terbentuk diamati dengan menggunakan software BIOVIA Discovery Studio 2020.

\section{HASIL DAN PEMBAHASAN}

Agen terapi yang memiliki aktivitas lebih baik dengan efek samping minimum saat ini menjadi suatu kebutuhan penting untuk mengobati gangguan trombotik. Kelemahan utama dari antikoagulan konvensional adalah masih tingginya faktor risiko pendarahan. Peptida bioaktif dapat dianggap sebagai pilihan ideal untuk terapi antikoagulasi yang lebih aman karena sifatnya yang lebih spesifik terhadap target. Sejauh ini, terdapat peningkatan jumlah penelitian yang melaporkan peptida antikoagulan dari berbagai sumber, akan tetapi data mengenai spesifisitas inhibisinya masih sedikit dan perlu untuk dipelajari lebih lanjut.

Penelitian sebelumnya telah membuktikan bahwa terdapat beberapa peptida bioaktif dari organisme laut yang telah berhasil dikarakterisasi, dipreparasi, dan dipurifikasi. Proses pembuatan peptida bioaktif ini memanfaatkan proses sintesis organik, Microwave Assisted Extraction (MAE), hidrolisis kimia, dan hidrolisis enzim. Kemudian tahapan selanjutnya dilakukan proses pemurnian peptida bioaktif menggunakan kromatografi eksklusi gel, kromatografi penukar ion, dan kromatografi cair kinerja tinggi. Sekuensing peptida bioaktif yang memiliki aktivitas terhadap enzim sitokrom P450 (CYP) 2C9, diantaranya TDGSEDYGILEIDSR yang berasal dari ikan tuna sirip kuning (Limanda aspera) dan EADIDGDGQVNYEEFVAMMTSK yang berasal dari kerang biru (Mytilus edulis) (Wang et al., 2017).

Struktur makromolekul enzim sitokrom P450 (CYP) 2C9 dipilih sebagai target untuk kedua molekul peptida bioaktif. Makromolekul tersebut terlebih dahulu dilakukan preparasi dengan menghilangkan molekul air dan ligan alami yaitu warfarin, kemudian tahapan selanjutnya menambahkan atom hidrogen polar, dan menghitung muatan parsial Kollman dengan menggunakan software MGLTools 1.5.6 yang dilengkapi dengan AutoDock 4.2 (Kurniawan et al., 2018). Tahapan preparasi makromolekul ini bertujuan untuk memastikan agar molekul peptida bioaktif dapat membentuk interaksi yang stabil dengan makromolekul enzim. Selain itu, warfarin yang telah membentuk kompleks dengan enzim sitokrom P450 (CYP) 2C9 digunakan sebagai molekul pembanding untuk mengamati interaksi dan afinitas yang paling baik. 


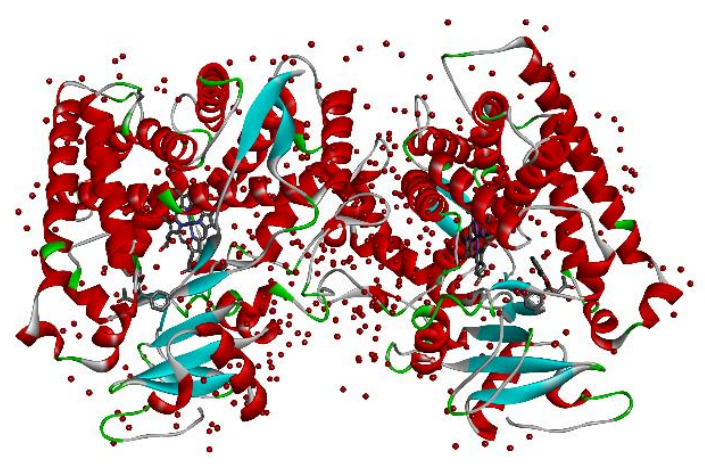

Gambar 1. Struktur kristal makromolekul enzim sitokrom P450 (CYP) 2C9 yang telah membentuk kompleks dengan warfarin.

Makromolekul enzim sitokrom P450 (CYP) 2C9 yang telah dipreparasi kemudian dilakukan dentifikasi dan evaluasi bagian sisi aktifnya dengan menggunakan software BIOVIA Discovery Studio 2020 sehingga sifat dan karakteristik dari area pengikatan pada enzim sitokrom P450 (CYP) 2C9 dapat diketahui secara detail. Seperti yang ditunjukkan pada Gambar 2, interaksi yang terjadi antara enzim sitokrom P450 (CYP) 2C9 dengan warfarin meliputi 2 ikatan hidrogen (dengan Ile99 dan Phe100) dan 11 interaksi hidrofobik (dengan Phe100, Ala103, Phe114, Leu366, dan Pro367). Berdasarkan hasil pengamatan tersebut maka dapat diprediksi bahwa residu asam amino tersebut berperan sebagai komponen penyusun dari sisi aktif pengikatan makromolekul enzim sitokrom P450 (CYP) 2 C9.
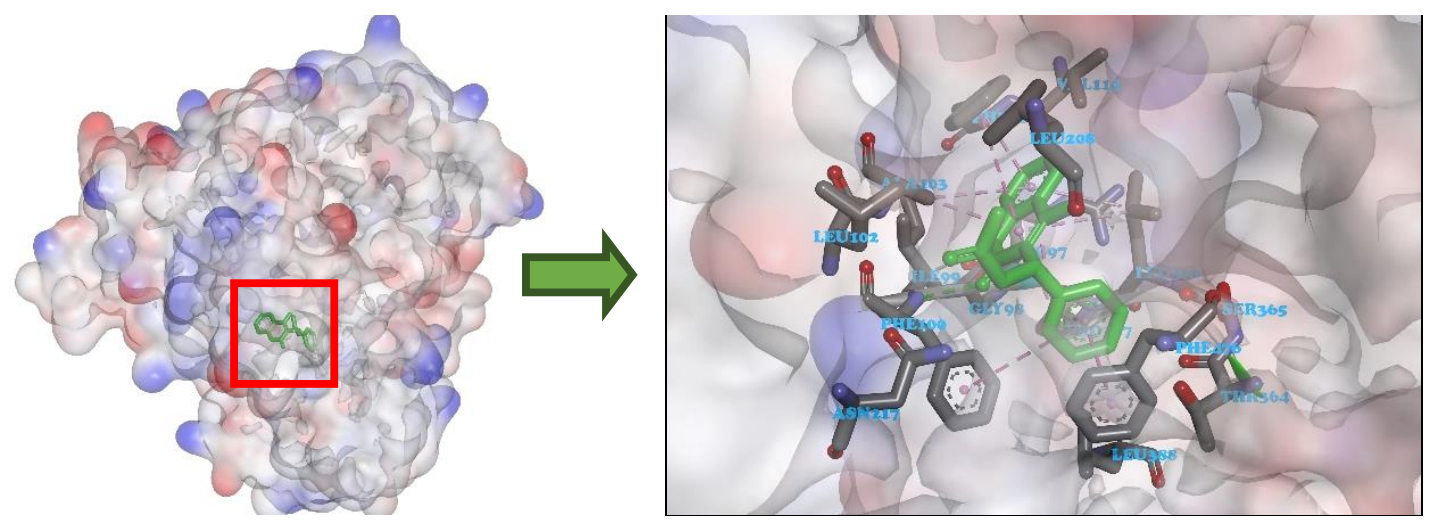

Gambar 2. Bagian sisi aktif pengikatan makromolekul enzim sitokrom P450 (CYP) 2 C9.

Pemodelan sekuensing peptida bioaktif menjadi struktur tiga dimensi dilakukan dengan menggunakan server PEP-FOLD. Konformasi hasil pemodelan molekul peptida bioaktif terbaik dipilih berdasarkan energi sOPEP (Optimized Potential for Efficient Structure Prediction) (Thevenet et al., 2012; Shen et al., 2014). Energi sOPEP ini sudah terintegrasi dalam server PEP-FOLD digunakan untuk menggambarkan konformasi struktur peptida bioaktif yang dimodelkan sehingga mendekati keadaan aslinya dan diharapkan mampu menghasilkan suatu interaksi yang stabil dengan makromolekul enzim target. Berdasarkan hasil pemodelan molekul peptida bioaktif yang terdapat pada Gambar 3 dapat diprediksi bahwa peptida tersebut akan mampu berinteraksi dengan baik pada area sisi aktif pengikatan enzim sitokrom P450 (CYP) 2C9. 


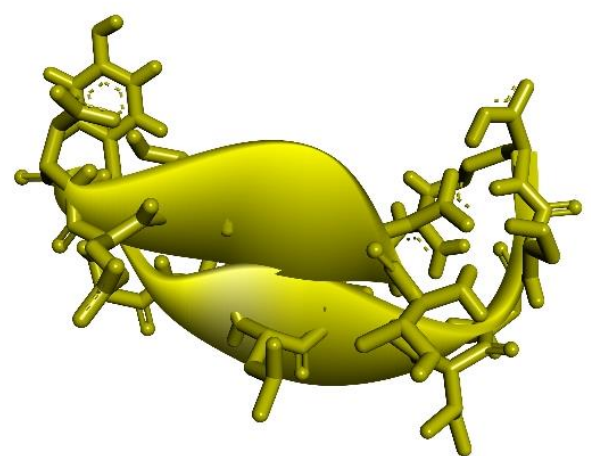

TDGSEDYGILEIDSR

Ikan tuna sirip kuning (Limanda aspera)

Energi SOPEP $=-18,34$

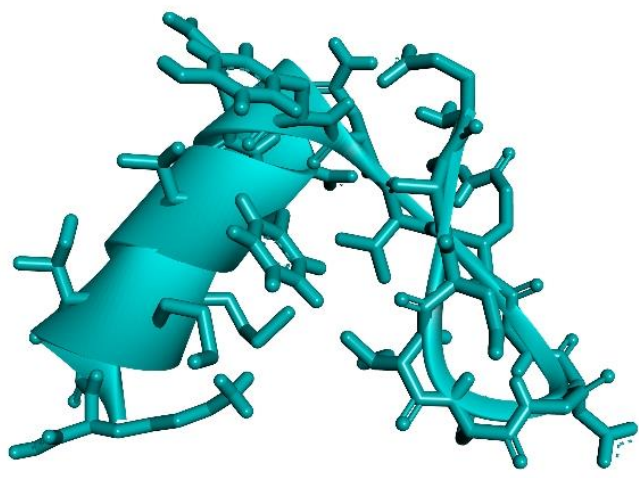

EADIDGDGQVNYEEFVAMMTSK

Kerang biru (Mytilus edulis)

Energi sOPEP $=-30,91$

Gambar 3. Hasil pemodelan tiga dimensi sekuensing molekul peptida bioaktif yang berasal dari organisme laut.

Studi penambatan molekuler berbasis protein-peptida dilakukan dengan menggunakan software PatchDock untuk mengamati afinitas paling baik diantara kedua molekul peptida bioaktif, serta mengidentifikasi dan mengevaluasi interaksi yang terlibat terhadap makromolekul enzim sitokrom P450 (CYP) 2C9. Model pengikatan protein-peptida dengan konformasi terbaik hasil penambatan molekuler dipilih berdasarkan PatchDock score, selanjutnya molekul peptida bioaktif tersebut dibandingkan berdasarkan Atomic Contact Energy (ACE) score (Prabhu dan Rajeswari, 2016). Berdasarkan data hasil penambatan molekuler yang terdapat pada Tabel 1 menunjukkan bahwa molekul peptida bioaktif TDGSEDYGILEIDSR yang berasal dari ikan tuna sirip kuning (Limanda aspera) memiliki afinitas yang lebih baik apabila dibandingkan dengan EADIDGDGQVNYEEFVAMMTSK yang berasal dari kerang biru (Mytilus edulis) dan warfarin, yaitu dengan ACE score masing-masing adalah $-2527,01$ $\mathrm{kJ} / \mathrm{mol}$, 464,63 kJ/mol, dan $-1070,31 \mathrm{~kJ} / \mathrm{mol}$. Hal tersebut dapat diprediksi bahwa lokasi tempat pengikatan peptida ikan tuna sirip kuning tidak jauh berbeda dengan warfarin (Veeraragavan et al., 2017).

Tabel 1. Energi bebas pengikatan hasil studi penambatan molekuler berbasis protein-peptida.

\begin{tabular}{ccccc}
\hline $\begin{array}{c}\text { Molekul } \\
\text { Pembanding }\end{array}$ & $\begin{array}{c}\text { Organisme } \\
\text { Laut }\end{array}$ & Sekuensing Molekul Peptida Bioaktif & $\begin{array}{c}\text { PatchDock } \\
\text { score }\end{array}$ & $\begin{array}{c}\text { ACE score } \\
(\mathrm{kJ} / \mathrm{mol})\end{array}$ \\
\hline Warfarin & & 5014 & $-1070,31$ \\
& $\begin{array}{c}\text { Ikan tuna } \\
\text { sirip kuning } \\
\text { (Limanda } \\
\text { aspera })\end{array}$ & TDGSEDYGILEIDSR & 7946 & $-2527,01$ \\
& $\begin{array}{c}\text { Kerang biru } \\
(\text { Mytilus } \\
\text { edulis })\end{array}$ & EADIDGDGQVNYEEFVAMMTSK & 8806 & 464,63 \\
& & & \\
\hline
\end{tabular}


Selanjutnya, dilakukan identifikasi dan evalusi lebih lanjut terhadap visualisasi dari kompleks molekul peptida bioaktif dan makromolekul enzim sitokrom P450 (CYP) 2C9. Sebagaimana yang ditunjukkan pada Gambar 4, dapat diamati bahwa peptida TDGSEDYGILEIDSR yang berasal dari ikan tuna sirip kuning (Limanda aspera) memiliki kemiripan posisi pengikatan dengan warfarin, sedangkan peptida EADIDGDGQVNYEEFVAMMTSK yang berasal dari kerang biru (Mytilus edulis) berada jauh di luar area sisi aktif pengikatan makromolekul enzim. Kemudian apabila dieksplorasi berdasarkan interaksi yang terbentuk, peptida ikan tuna sirip kuning memiliki ikatan yang lebih banyak dibandingkan peptida kerang biru. Interaksi yang terbentuk dari kompleks peptida ikan tuna sirip kuning dan enzim sitokrom P450 (CYP) 2C9 terdiri dari 22 interaksi yang meliputi 9 ikatan hidrogen (dengan Leu208, Asn217, Glu300, Thr305, Cys435, Phe428, dan Glu438), 10 interaksi hidrofobik (dengan Phe100, Val113, Leu233, Ala297, Leu366, Pro367, Arg433, Cys435, dan Phe476), dan 3 interaksi elektrostatik (dengan Arg97 dan Phe114). Sementara, interaksi yang terbentuk antara peptida kerang biru dengan enzim sitokrom P450 (CYP) 2C9 hanya 13 interaksi antara lain terdapat 5 ikatan hidrogen (dengan Asn107, Arg108, Gly109, Lys 118, dan Thr371), 4 interaksi hidrofobik (dengan Ile99, Phe110, Lys118, dan Lys119), dan 4 interaksi elektrostatik (dengan Lys72, Arg108, Phe110, dan Lys383). Dengan demikian, fenomena ini membuktikan bahwa ACE score positif dari kompleks peptida bioaktif kerang biru dan makromolekul enzim sitokrom P450 (CYP) 2C9 dapat disebabkan karena molekul peptida tersebut tidak berikatan pada area sisi aktif target (Norel et al., 2001).

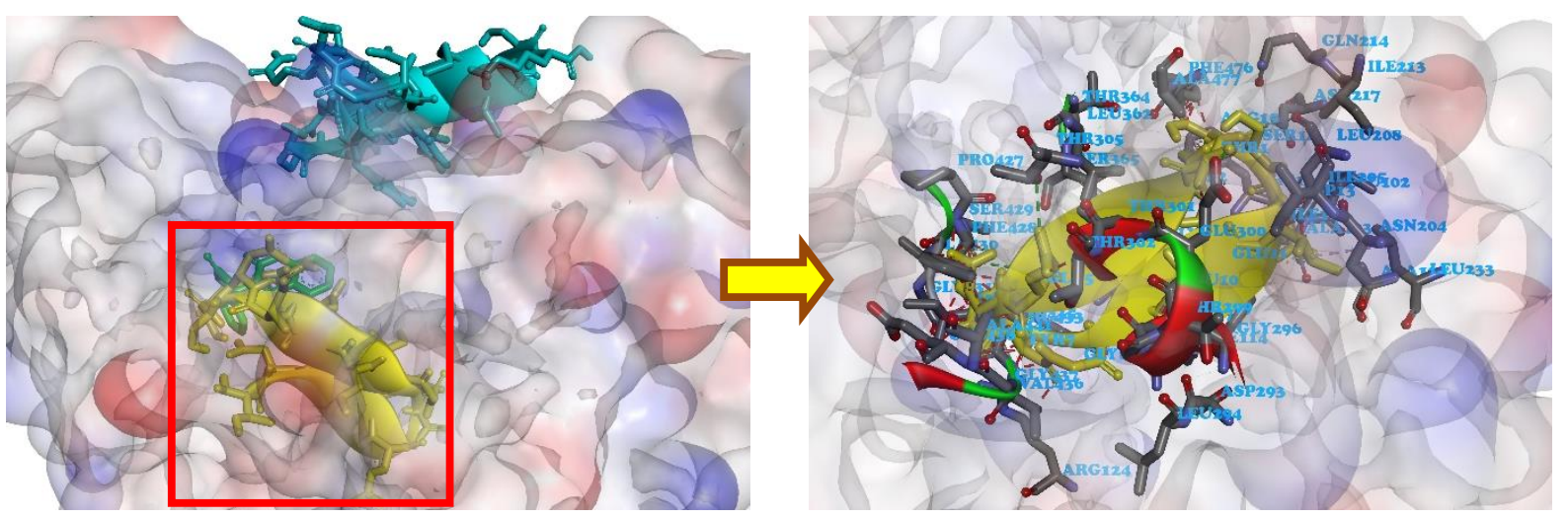

Gambar 4. Pose pengikatan pada makromolekul enzim sitokrom P450 (CYP) 2C9 dan interaksi yang terbentuk oleh peptida bioaktif ikan tuna sirip kuning (Limanda aspera).

\section{KESIMPULAN}

Molekul peptida bioaktif yang berasal dari ikan tuna sirip kuning (Limanda aspera) telah terbukti mampu menghambat enzim sitokrom P450 (CYP) 2C9 melalui identifikasi dan evaluasi terhadap interaksi molekuler yang terjadi dengan menggunakan metode penambatan molekuler berbasis proteinpeptida secara in silico. Berdasarkan hasil penambatan molekuler diperoleh bahwa molekul peptida tersebut memiliki afinitas yang baik terhadap sisi aktif pengikatan makromolekul enzim sitokrom P450 (CYP) 2C9 yaitu dengan ACE score $-2527,01 \mathrm{~kJ} / \mathrm{mol}$. Dengan demikian, peptida bioaktif tersebut memiliki potensi sebagai kandidat inhibitor enzim sitokrom P450 (CYP) 2C9 untuk pengembangan antikoagulan alami berbasis peptida. 


\section{DAFTAR PUSTAKA}

Ahmed, I., Majeed, A., \& Powell, R. (2007). Heparin induced thrombocytopenia: diagnosis and management update. Postgrad Med J, 83, 575-582. https://doi.org/10.1136/pgmj.2007.059188

Akif, M., Masuyer, G., Schwager, S.L.U., Bhuyan, B.J., Mugesh, G., Isaac, R.E., Sturrock, E.D., \& Acharya, K.R. (2011). Structural characterization of angiotensin I-converting enzyme in complex with a selenium analogue of captopril. FEBS J, 2011, 278, 3644-3650. http://doi.org/10.1111/j.1742-4658.2011.08276.x

Alquwaizani, M., Buckley, L., Adams, C., \& Fanikos, J. (2013). Anticoagulants: a review of the pharmacology, dosing, and complications. Curr Emerg Hosp Med Rep, 1, 83-97. https://doi.org/10.1007/s40138-013-0014-6

Aruleba, R.T., Adekiya, T.A., Oyinloye, B.E., \& Kappo, A.P. (2018). Structural studies of predicted ligand binding sites and molecular docking analysis of Slc2a4 as a therapeutic target for the treatment of cancer. Int J Mol Sci, 19. https://doi.org/10.3390/ijms19020386

Chavan, S.G., \& Deobagkar, D.D. (2015). An in silico insight into novel therapeutic interaction of LTNF Peptide-LT10 and design of structure based peptidomimetics for putative anti-diabetic activity. PLoS One, 10, e0121860. https://doi.org/10.1371/journal.pone.0121860

Franchini, M., \& Mannucci, P.M. (2016). Direct oral anticoagulants and venous thromboembolism. Eur Respir Rev, 25, 295-302. https://doi.org/10.1183/16000617.0025-2016

Harter, K., Levine, M., \& Henderson, S.O. (2015). Anticoagulation drug therapy: a review. West J Emerg Med, 16, 11-17. https://doi.org/10.5811/westjem.2014.12.22933

Hawkins, D. (2004). Limitations of traditional anticoagulants. Pharmacother, 24, 62-65. https://doi.org/10.1592/phco.24.10.62s.36120

Jung, W.K., \& Kim S.K. (2009). Isolation and characterisation of an anticoagulant oligopeptide from blue mussel, Mytilus edulis. Food Chem, 117, 687-692. https://doi.org/10.1016/j.foodchem.2009.04.077

Katritsis, D.G., Gersh, B.J., \& Camm, A.J. (2015). Anticoagulation in atrial fibrillation current concepts. Arrhythm Electrophysiol Rev, 4, 100-107. https://doi.org/10.15420/aer.2015.04.02.100

Kemmish, H., Fasnacht, M., \& Yan, L. (2017). Fully automated antibody structure prediction using BIOVIA tools: Validation study. PLoS One, 12, e0177923. https://doi.org/10.1371/journal.pone.0177923

Kurniawan, F., Miura, Y., Kartasasmita, R.E., Yoshioka, N., Mutalib, A., \& Tjahjono, D.H. (2018). In silico study, synthesis, and cytotoxic activities of porphyrin derivatives. Pharmaceuticals, 11, 8. https://doi.org/10.3390/ph11010008

Mackman, N. (2012). New insights into the mechanisms of venous thrombosis. J Clin Investig, 122, 2331-2336. https://doi.org/10.1172/JCI60229.paralysis

Mega, J.L., \& Simon, T. (2015). Novel antithrombotic agents 1 pharmacology of antithrombotic drugs: an assessment of oral antiplatelet and anticoagulant treatments. Lancet, 386, 281-291. https://doi.org/10.1016/S0140-6736(15)60243-4 
Norel, R., Sheinerman, F., Petrey, D., \& Honig, B. (2001). Electrostatic contributions to protein-protein interactions: Fast energetic filters for docking and their physical basis. Protein Sci, 10, 2147-2161. https://doi.org/10.22159/10.1110/ps.12901

Patterson, S.L., LaMonte, M.P., Mikdashi, J.A., Haines, S.T., \& Hursting, M.J. (2006). Anticoagulation strategies for treatment of ischemic stroke and antiphospholipid syndrome: case report and review of the literature. Pharmacotherapy, 26, 1518-1525. https://doi.org/10.1592/phco.26.10.1518

Prabhu, D.S., \& Rajeswari, V.D. (2016). In silico docking analysis of bioactive compounds from Chinese medicine Jinqi Jiangtang Tablet (JQJTT) using Patch Dock. J Chem Pharm Res, 8, 1521.

Rajapakse, N., Jung, W.K., Mendis, E., Moon, S.H., \& Kim, S.K. (2005). A novel anticoagulant purified from fish protein hydrolysate inhibits factor XIIa and platelet aggregation. Life Sci, 76, 2607-2619. https://doi.org/10.1016/j.lfs.2004.12.010

Raskob, G.E., Angchaisuksiri, P., Bianco, A.N., Buller, H., Gallus, A., Hunt, B.J., Hylek, E.M., Kakkar, A., Konstantinides, S.V., McCumber, M., Ozaki, Y., Wendelboe, A., \& Weitz, J.I. (2014). Thrombosis: a major contributor to the global disease burden. J Thromb Haemost, 12, 1580-1590. https://doi.org/10.1111/jth.12698

Shen, Y., Maupetit, J., Derreumaux, P., \& Tuffery, P. (2014). Improved PEP-FOLD approach for peptide and miniprotein structure prediction. J Chem Theory Comput, 10, 4745-4758. https://doi.org/10.1021/ct500592m

Snipelisky, D., \& Kusumoto, F. (2013). Current strategies to minimize the bleeding risk of warfarin. $J$ Blood Med, 4, 89-99. https://doi.org/10.2147/JBM.S41404

Suguna, S., Kunkulol, R., Kumar, V., Ambadasu, B., \& Nandal, D.H. (2014). Affinity of warfarin with cyp2c9 by molecular docking study. Int J Pharm Pharm Sci. 6, 181-182.

Thevenet, P., Shen, Y., Maupetit, J., Guyon, F., Derreumaux, P., \& Tuffery, P. (2012). PEP-FOLD: an updated de novo structure prediction server for both linear and disulfide bonded cyclic peptides. Nucleic Acids Res, 2012, 40, 288-293. https://doi.org/10.1093/nar/gks419

Veeraragavan, V., Narayanaswamy, R., \& Chidambaram, R. (2017). Predicting the biodegradability nature of imidazole and its derivatives by modulating two histidine degradation enzymes (urocanase and formiminoglutamase) activities. Asian J Pharm Clin Res, 10, 383-386. https://doi.org/10.22159/ajpcr.2017.v10i11.20999

Wang, X., Yu, H., Xing, R., \& Li, P. (2017). Characterization, preparation, and purification of marine bioactive peptides. Biomed Res Int, 9746720. https://doi.org/10.1155/2017/9746720 